\title{
CORPORATE SOCIAL RESPONSIBILITY AND LEVERAGE LEVEL ON HIGH PROFILE INDUSTRIES AT INDONESIAN STOCK EXCHANGE OF 2015-2019 PERIOD
}

\author{
Liliana Inggrit Wijaya \\ Department of Management, Faculty of Business and Economics, University of Surabaya \\ Email: liliana@staff.ubaya.ac.id (corresponding author) \\ Arif Herlambang \\ Department of Management, Faculty of Business and Economics, University of Surabaya \\ Email: arif_herlambang@staff.ubaya.ac.id \\ Billy Evans \\ Department of Management, Faculty of Business and Economics, University of Surabaya \\ Email: bill.bm98@gmail.com
}

Received: Juni 2021; Accepted: November 2021; Available online: January 2022

\begin{abstract}
This study aims at analyzing the effect of corporate social responsibility (CSR) and the level of use of debt on financial performance. The variables used in this study included corporate social responsibility, debt, age, size and employees. This study uses a quantitative paradigm with the least square regression panel data processing method. The population in this study is all non-financial sector companies included in the high profile industry category at the Indonesia Stock Exchange (ISE) for the 2015-2019 period. The results prove that CSR has a significant positive effect on financial performance as proxied by Tobin's Q. When a company's CSR is high, it will have a positive impact on its financial performance. Then, leverage has a negative effect on the performance because the higher the debt, the lower the company's performance.
\end{abstract}

Keywords: Corporate Social Responsibility; Leverage; Financial Performance; Tobin’s Q.

\begin{abstract}
Abstrak
Penelitian ini bertujuan untuk menganalisis pengaruh tanggung jawab sosial perusahaan (CSR) dan tingkat penggunaan utang terhadap kinerja keuangan. Variabel yang digunakan pada penelitian ini yaitu tanggung jawab sosial perusahaan, utang, usia, ukuran dan karyawan. Penelitian ini menggunakan paradigma kuantitatif dengan metode pengolahan data panel least square regression. Populasi pada penelitian ini adalah seluruh perusahaan sektor non-keuangan yang termasuk dalam kategori industri high profile di Bursa Efek Indonesia (BEI) periode 2015-2019. Hasil penelitian membuktikan bahwa CSR berpengaruh positif signifikan terhadap kinerja keuangan yang diproksi dengan Tobin's Q. Ketika CSR suatu perusahaan tinggi maka akan berdampak positif dengan kinerja keuangannya. Kemudian untuk leverage mempunyai hubungan negatif terhadap kinerja karena semakin tinggi utang akan menurunkan kinerja perusahaan.
\end{abstract}

Kata kunci: Tanggung Jawab Sosial; Leverage; Kinerja Keuangan; Tobin's $Q$.

How to Cite: Wijaya, L. I., Herlambang, A., \& Evans, B. (2022). Corporate Social Responsibility and Leverage Level on High Profile Industries at Indonesian Stock Exchange of 2015-2019 Period. Media Ekonomi dan Manajemen, 37(1), 1-16. doi: http://dx.doi.org/10.24856/mem.v37i1.2285. 


\section{INTRODUCTION}

The tight business competition makes companies in today's era have to adopt many strategies in order to survive. This is very important because basically the main goal of the company is to maximize the value of the company or the wealth of the owner of the company. One of the ways companies in maximizing the value of the company is to improve financial performance. Financial performance has a significant role for management in making decisions. Financial performance is a measure of the company's success in managing and allocating resources in order to achieve what the company's goals have been (Rahmawardani and Muslichah, 2020). When the company develops, it is not only the needs of the shareholders that must be considered, but also the satisfaction of the stakeholders towards the company as one of the pillars and important determinants for the sustainability of the company's financial performance.

Many companies formerly known as large and successful companies with good image, has now dimmed and declined in their business activities and even gone out of business. The increasingly tighter business competition makes the company try its best to contribute to the stakeholders. The companies cannot only rely on high profits since there are other aspects that can actually affect a company's image or reputation in the eyes of the public, namely, corporate social responsibility (CSR) (Mishra and Suar, 2010; Jo and Harjoto, 2011; Barnett, 2016; Aguinis and Glavas (2012). This aspect is considered very crucial for the company because this program will help the company have a positive impact, especially on the people who are part of the company's stakeholders (Brown et al., 2006).

Environmental issues that have been sticking out lately are things which should be considered by companies in carrying out their business activities. Usually, for the aspects of employee welfare and product development, most companies are already concerned about this. Meanwhile, there are other things that are also crucial and require special attention when a company runs its business operations because it can have an impact on many parties, namely the problem of the company's concern for the environment. Apart from being profit-oriented, it is time for businesses today to pay more attention to environmental conditions. Some companies have even implemented strategies, policies and activities in carrying out their environmentally friendly business activities in order to protect the existing natural environment (Raiborn et al., 2013; Chandra et al., 2015). Because of the crucial importance of environmental issues in the company's CSR programs, this issue should be a serious concern for the company. This environmental issue has also become the center of attention from a number parties, including the government, as outlined in Law No. 40 of 2007 on Limited (Ltd) Companies, Government Regulation No. 47 of 2012 concerning Social and Environmental Responsibility of Limited (Ltd) Companies. A good company certainly will not only care about its own interests and profits because companies are expected to be accountable not only to shareholders but also to society as a whole (Kim et al., 2017; Gibson, 2000).

As a form of social responsibility from the company, caring for the environment can be implemented by carrying out environmental disclosure (Bazillier et al., 2017). Environmental disclosure actions taken by the company will show how concerned the company is with environmental problems that exist in carrying out its social responsibility. Environmental disclosures that are increasingly appearing will also affect company performance and help companies get bigger opportunities because investors will be increasingly interested and willing to invest in the company. Research by 
Muttakin \& Subramaniam (2015) showed that the more social and environmental disclosures, the better the company's performance. Investors can judge that a company with a good environmental responsibility will have a small risk so that this is an opportunity for the company to get a bigger capital injection and will have an impact on company performance. The stakeholder theory that has been stated earlier can be used to answer the relationship between corporate social responsibility and corporate financial performance. Stakeholders have the ability to influence the use of economic resources that will be used by the company. It could be that the strength of stakeholders can be seen from the size of the stakeholder's portion of the available resources. In this theory, it is assumed that the implementtation of CSR by the company will improve the company performance. This is because the stakeholders trust the company and they will provide full support for all actions that the company will take as long as they do not violate the law. The company's performance will also increase along with the development of a good "image" or good reputation in the minds of the company's stakeholders. When the company can pay attention to the needs of its stakeholders well, it will raise the image and lift the company's reputation so that it will linearly improve the company's performance.

Another factor that affects financial performance is debt as a catalyst commonly used by companies to achieve goals. Debt is an economic sacrifice that a company will have to make in the future because of previous actions or transactions. Tsoutsoura (2010) and Ali (2020) found that leverage is negatively related to financial performance because greater debt has the potential to increase the risk of the company so that investors are hesitant to invest in the company. The use of debt will determine the level of financial leverage of the company because if there is more debt than own capital, the fixed burden borne by the company will be high, which can reduce the financial performance (Shaferi et al., 2020).

The age of the company also determines the company's financial performance. Companies that have been set up for a long time generally have a reputation and will be better known by many people. In addition to the ability to compete, companies with longer establishments have more capabilities and resources to fight new competitors because they are more familiar with their business environment (Abdi et al., 2021).

Firm size is described as the natural logarithm of total assets. Large companies usually have great financial strength as well. According to Yusof et al. (2020) company size is the right scale to measure or determine the size of the company seen from the assets or resources it has. Companies that have large resources make it easier for companies to get funding sources and diversify their business (Phoprachak and Buntornwon, 2020).

Firm employees are those who are parts of the company, both those who have worked for a long time and those who have just joined (Soewarno and Tjahjadi, 2020). Employees here can also be assumed as the number of people who work in a company and become one of the determinants of the company's financial performance (Surroca et al. 2010, Tangngisalu et al., 2020).

The novelty of this research is seen in the inclusion of non-financial companies that are included in the high profile industry criteria, namely companies that are stigmatized because they have a high level of sensitivity to the environment, strong regulation and competition (Kim et al., 2017; Bazillier et al., 2017).This occurs due to its characteristics as having a large number of workers and in the production process it emits residues, such as waste and pollution.

The novelty also can be seen in terms of linking CSR with financial performance in high profile industries. This research contributes by expanding the theory of 
disclosure with a content analysis approach which proves empirically that environmental risk information is used by investors. It is believed that the disclosure of social responsibility information is more often carried out by high profile industries than low profiles (Benlemlih et al., 2018; Ozdemir \& Kim, 2020).

This research also contributes to developing legitimacy theory and stakeholder theory. In legitimacy theory, CSR is considered part of the social contract so that CSR can be a guideline and strategy for companies (Yang et al., 2017) to convey responsibilities according to the environment and business risks (Devie et al., 2019; Ozdemir \& Kim, 2020). Stakeholder theory believes that companies have strong incentives to maintain good relations with various stakeholders through CSR (Cho \& Chun, 2015).

The rest of paper proceeds as follows. Section 2 reviews the related literature and proposes a hypothesis. Section 3 describes the sample construction and research model as well as statistical testing. Sections 4 and 5 present the empirical strategy and discuss the main results. Section 6 presents the conclusions, implications, suggestions, and limitations. Introduction.

\section{LITERATURE REVIEW}

\section{CSR Theory and Environmental Disclosure}

Financial reporting and disclosure is an important aspect for management to inform investors about corporate performance and governance. Disclosures made by the company can be done through several media, including company financial reports, footnotes, discussions, and management analysis. In addition, companies can also make voluntary disclosures such as analyst presentations, press releases, internet sites, and other company reports (Healy and Palepu, 2001). Disclosure theory implies that managers have more information than investors about the company's current and future performance. Greater disclosure can reduce the asymmetry of existing information (Leuz, 2000).

According to Setyawan and Zulaikha (2012), environmental disclosure is a company disclosure of the impact of company activities on the physical environment in which the company operates. By doing a lot of disclosure, the company's stakeholders will know more clearly what the company is doing in carrying out environmental CSR so that it can reduce the occurrence of information asymmetry. Recognizing the expectation of stakeholders for company activities will be a competitive advantage of the company to create opportunities in order to meet the needs of its stakeholders and this can help the long-term competitiveness of the company (Ferraris et al., 2018).

As the manifestation of environmental concern, environmental disclosures can be carried out to show how open the company is to environmental problems that exist in carrying out its social responsibility. Schnackenberg and Tomlinson (2016) stated that company transparency creates positive things because it can reduce information asymmetry between the company and its stakeholders.

The increasing environmental disclosures can affect the company's performance so that it helps the company get bigger opportunities because investors will be increasingly interested and willing to invest in the company. Investors can judge companies with good environmental responsibility to have a small risk so that this is an opportunity for the company to get a bigger capital injection and will have an impact on company performance (Linsey and Shrives, 2006).

\section{CSR and Financial Performance in High Profile Industries}

Based on the stakeholder theory proposed by Freerman (1994), CSR can 
improve the relationship between stakeholders associated with the company and this will have a significant positive impact on the company's financial performance (Feng et al., 2017; Sial et al., 2018; Yoon and Chung, 2018; Nyeadi et al., 2018). One of the ways that companies can do is by making disclosures. This disclosure is made so that the company is more transparent in exposing existing information to stakeholders so that it can reduce the asymmetry of existing information. Linsey and Shrives (2006) stated that companies in high profile industries that choose to conduct high disclosures will actually be considered good because they provide more information and this makes the company less risky than before and this will attract more market players.

It is further explained that the additional expenditure in social matters can improve stakeholder relations with the company and can reduce corporate social costs and increase market opportunities for the company. Statman and Glushkov (2009) also stated that companies that get a high CSR rating have a higher rate of return than companies with a low CSR rating. This improves the image and reputation of the company, which of course will be in line with the increase in company performance. Accordingly, the company can have a more competitive advantage over its competitors.

Jo and Harjoto (2011) prove that companies that carrying out CSR have a positive impact on the financial performance because CSR can solve conflicts that arise between managers and stakeholders. Chiu and Sharfman (2011) explain that when a company takes a CSR approach with high tension it can be seen as an intangible asset or social capital for the company that has a better impact on performance. CSR can facilitate a company to build a company's image and legitimacy, to take advantage of existing opportunities and to get the protection from external threats so that in the end it also maximizes profits (Barnett, 2016).
$\mathrm{H}_{1}$ : Corporate Social Responsibility has positive impact on the company financial performance.

\section{Leverage Levels and Financial Performance}

Leverage is an important instrument in a company because to run its business, companies may not drain their cash when they want to expand their business. Of course, in using leverage, a company should carefully estimate the amount and ability to pay if the company does not want leverage to have a bad impact. In Yoon and Chung (2018), it is stated that by committing debt, companies will be able to enjoy a tax protection so that it allows companies to pay less tax obligations than companies that do not. The findings of Yoon and Chung (2018) contradict the findings of Feng et al. (2017) and Kao et al. (2018) who state that going into debt will actually burden the company's finances because there is interest that must be paid and the company will be forced to continue to increase income and if this cannot be achieved, the company will be very disadvantaged. It is supported by Tsoutsoura (2010) and Ali (2020) who proves that leverage is negatively related to financial performance because if the company's debt is greater, it will increase the company's risk. This condition can make investors afraid to invest their money in the company. The use of debt will determine the level of the company's financial leverage because if it uses more debt than its own capital, the fixed burden to be borne by the company becomes high and this condition can make the company's performance to decline (Yoon and Jang, 2005; Shaferi et al., 2020).

$\mathrm{H}_{2}$ : Company leverage has negative impact on the company financial performance.

\section{RESEARCH METHODS}

This research used all non-financial companies listed at the Indonesia Stock Exchange for the period 2015-2019 and included in the criteria of high profile 
industry. Characteristics of the sample in this study were as follows: (1) business entities in the agriculture, mining and manufacturing sectors listed at the Indonesia Stock Exchange in a row for the 2015-2019 period, (2) having and publishing financial and annual reports for the 2015-2019 period, (3) data were available for all variables required in the financial statements, (4) not conducting IPOs in the near future or during the research period.

The variables used in this study were corporate social responsibility and leverage as independent variables. CSR was measured from the number of negative expressions such as damage, pollution, disasters, decline, challenge, loss, failure, which reflect the potentials of loss and risks for the company. Method used to measure the environmental disclosure was content analysis. The value of number of words found in the content analysis was counted. Number of words more than median value $=1$, less than median value $=$ 0 .

Tests on samples based on categories will be carried out in the additional analysis section or robustness testing. The first was the grouping of samples into two industrial categories, mining and nonmining, because mining groups in their operational activities have a more significant impact on the environment. The second was the grouping based on environmental impact, to see whether disclosure of environmental information was more responsive to certain categories.

Leverage is a debt instrument used by the company to meet the company's operational needs both in the short and long term, measured by the ratio of total debt divided by the total asset value of the company i year $t$.

The dependent variable is financial performance as measured by Tobin's Q (Berezinets et al., 2017) which is obtained from market capitalization minus book value from equity, long-term debt divided by total company assets i year t. .
Control variables are firm age (calculated from the log since the company was founded minus the year IPO), firm size (in total assets), and firm employee (in number of employees).

The type of data used in this study was secondary data because the data here was obtained from the financial reports of all non-financial sector business entities and those included in the high profile industry starting from the 2015-2019 period. The data were obtained from financial reports and annual reports, not from survey results through a questionnaire distribution mechanism.

This study used multiple linear regression analysis-balanced panel data, with formula:

$\mathrm{FP}_{\text {it }}=\beta_{0}+\beta_{1}$ DummyCSR $_{\text {it }}+\beta_{2} \mathrm{LEV}_{\mathrm{i}, \mathrm{t}}+$ $\beta_{3} \mathrm{AGE}_{\mathrm{i}, \mathrm{t}}+\beta_{4} \operatorname{lnSIZE} \mathrm{it}_{\mathrm{it}}+\beta_{5} \mathrm{EMP}_{\mathrm{it}}+\varepsilon_{\mathrm{it}}(1)$

$\mathrm{FP}_{\text {it }}=$ company's financial performance,

DummyCSR $_{\text {it }}=$ corporate Social Responsibility, angka Dummy, $\mathrm{LEV}_{\mathrm{i}, \mathrm{t}}=$ company debt / leverage, $\mathrm{AGE}_{\mathrm{i}, \mathrm{t}}=$ the age of the company, $\operatorname{lnSIZE} E_{i t}=\ln$ company size, $\mathrm{EMP}_{\text {it }}=$ Company employees, $\beta_{1}, \beta_{2}, \beta_{3}, \beta_{4}, \beta_{5}=$ regression coefficient, $\varepsilon=$ error term.

\section{RESULT AND DISCUSSION}

\section{Result}

In the Tobin's $\mathrm{Q}$, the minimum value is obtained from the 2015 INRU company while the maximum value is obtained from the 2017 UNVR company. As seen Table 1 , the median value is 0 , which means that the majority of companies do a little negative word disclosure. This means that most of the CSR implemented by the company is high. Then, the second independent variable used in this study is leverage. The maximum value on leverage is obtained from the BIMA company in 2015 while the minimum value obtained from the 2019 DLTA company is 0.000149. Regarding the firm age, the 
minimum value is obtained from the WTON 2015 company, while the maximum value is obtained from the BATA company 2019; (2) for the firm size, the minimum value is obtained from the BIMA company 2017 while the maximum value is obtained from the ASII company 2019; (3) for the firm employee, the minimum value is obtained from the 2015 LMSH company while the maximum value is obtained from the ASII 2018 company.
The results of the multicollinearity test in Table 2 indicate that there is no high correlation value in the dependent variable used in the sample of this study. This shows that the research data are free from multicollinearity.

The results of the $F$ test show a significance level of $<0.05$, meaning that CSR, leverage, age, size, and employee together affect Tobin's Q (regression model fit).

Table 1. Descriptive Statistics

\begin{tabular}{lrccccc}
\hline All firms & TOBINS_Q & CSR & LEV & FA & FS & EMP \\
\hline Mean & 1.272058 & 0.499174 & 0.479922 & 20.72066 & 29.04923 & 7.591270 \\
Median & 0.541000 & 0.000000 & 0.478367 & 23.00000 & 28.98203 & 7.557995 \\
Maximum & 22.36100 & 1.000000 & 3.029086 & 88.00000 & 33.49453 & 12.32891 \\
Minimum & 0.002000 & 0.000000 & 0.000149 & 1.000000 & 25.21557 & 3.332205 \\
Std. Dev. & 2.381023 & 0.500413 & 0.261442 & 10.52369 & 1.651260 & 1.605551 \\
\hline
\end{tabular}

Source: Eviews output

Table 2. Test Results of Multicollinearity

\begin{tabular}{lllrrrr}
\hline \multicolumn{1}{c}{ All firms } & TOBINS_Q & \multicolumn{1}{c}{ CSR } & \multicolumn{1}{c}{ LEV } & \multicolumn{1}{c}{ FA } & \multicolumn{1}{c}{ FS } & \multicolumn{1}{c}{ EMP } \\
\hline TOBINS_Q & 1.000000 & 0.040335 & -0.070632 & 0.119455 & 0.127846 & 0.095738 \\
CSR & 0.040335 & 1.000000 & 0.087461 & -0.207383 & 0.359619 & 0.116983 \\
LEV & -0.070632 & 0.087461 & 1.000000 & -0.066758 & 0.047539 & 0.127213 \\
FA & 0.119455 & -0.207383 & -0.066758 & 1.000000 & -0.103124 & -0.060502 \\
FS & 0.127846 & 0.359619 & 0.047539 & -0.103124 & 1.000000 & 0.761664 \\
EMP & 0.095738 & 0.116983 & 0.127213 & -0.060502 & 0.761664 & 1.000000 \\
\hline
\end{tabular}

Source: Eviews output 
Table 3. Test Result of Regression on Financial Performance (Tobin's Q) Model 1: All Samples

\begin{tabular}{lrrl}
\hline \multicolumn{1}{c}{ Variable } & Coefficient & \multicolumn{1}{c}{ t-Statistic } & Prob. \\
\hline C & 10.08506 & $7.950002^{* * *}$ & 0.0000 \\
CSR & -0.121446 & $-12.46977^{* * *}$ & 0.0000 \\
LEV & -0.691496 & $-12.04314 * * *$ & 0.0000 \\
FA & 0.007087 & $2.265534 * * *$ & 0.0239 \\
FS & -0.339057 & $-8.684951^{* * *}$ & 0.0000 \\
EMP & 0.168877 & $11.11458 * * *$ & 0.0000 \\
Adjusted R-squares & 0.741240 & & \\
F-statistic & 78.40143 & & \\
Prob. (F-statistic) & 0.000000 & & \\
\hline Source: Eviews
\end{tabular}

Source: Eviews output, $* * *=\operatorname{sig} 1 \%, * *=\operatorname{sig} 5 \%, *=10 \%$

Tobin's-q $=10.08506-0,121446$ CSR $-0,691496 \mathrm{LEV}+0,007087$ AGE $-0,339057 \operatorname{lnSIZE}+0,168877$ EMP

Table 4. Test Result of Regression on Financial Performance (Tobin's Q) Model 2: Mining Sector

\begin{tabular}{lrcl}
\hline \multicolumn{1}{c}{ Variable } & Coefficient & t-Statistic & Prob. \\
\hline C & 9.818500 & $5.055566^{* * *}$ & 0.0000 \\
CSR & 0.029732 & 1.256029 & 0.2123 \\
LEV & -1.522973 & $-10.09206^{* * *}$ & 0.0000 \\
FA & 0.047561 & $1.678380^{*}$ & 0.0967 \\
FS & -0.272021 & $-4.251847 * * *$ & 0.0001 \\
EMP & -0.111451 & -1.630312 & 0.1065 \\
Adjusted R-squares & 0.818464 & & \\
F-statistic & 20.16139 & & \\
Prob. (F-statistic) & 0.000000 & & \\
\hline Source: Eviews output, *** & &
\end{tabular}

Source: Eviews output, $* * *=\operatorname{sig} 1 \%, * *=\operatorname{sig} 5 \%, *=10 \%$

Tobin's-q $=9.818500+0.029732 \mathrm{CSR}-1.522973 \mathrm{LEV}+0.047561$ AGE - $0.272021 \operatorname{lnSIZE}-0.111451$ EMP 
Table 5. Test Result of Regression on Financial Performance (Tobin's Q) Model 3: Non-Mining Sector

\begin{tabular}{|c|c|c|c|}
\hline Variable & Coefficient & $\mathrm{t}$-Statistic & Prob. \\
\hline $\mathrm{C}$ & 11.53051 & $10.58614 * * *$ & 0.0000 \\
\hline CSR & 0.140020 & $2.246260^{* *}$ & 0.0253 \\
\hline LEV & -0.698016 & $-6.422393 * * *$ & 0.0000 \\
\hline FA & -0.009769 & $-1.538865^{*}$ & 0.1247 \\
\hline FS & -0.378920 & $-10.92690 * * *$ & 0.0000 \\
\hline EMP & 0.173635 & $5.076021 * * *$ & 0.0000 \\
\hline
\end{tabular}

\begin{tabular}{ll} 
Adjusted R-squares & 0.725224 \\
F-statistic & 60.29409 \\
Prob. (F-statistic) & 0.000000 \\
\hline
\end{tabular}

Source: Eviews output, $* * *=\operatorname{sig} 1 \%, * *=\operatorname{sig} 5 \%, *=10 \%$

Tobin's-q $=11.53051+0.140020 \mathrm{CSR}-0.698016 \mathrm{LEV}-0.009769$ AGE $-0.378920 \operatorname{lnSIZE}+0.173635$ EMP

\section{Discussion}

\section{The Effect of CSR on Tobin's Q.}

In Table 3 model 1 (all samples) shows that CSR has a significant negative effect on Tobin's Q. This result is in accordance with the hypothesis because companies that reveal slight negative things in their reporting have high CSR. High CSR has an impact on higher financial performance as well. This means that the reports made by the company are responded well by stakeholders. The company is not an entity that only operates for its own sake but must be able to provide benefits to stakeholders (Miranti and Henny, 2013; Masruhah et al., 2021).

In Table 4 model 2 (mining sector), CSR has no effect on financial performance. This finding contradicts the results of research by Feng et al. (2017), Sial et al. (2018), Nyeadi et al. (2018), and Yoon and Chung (2018). Feng et al. (2017) show that Tobin's $Q$ has a long-term nature, CSR should have a positive effect on financial performance. However, this study received support from Nur and Priantinah (2012) which proves that companies, especially those engaged in sectors that are vulnerable to the environment such as mining, need an image and reputation so that in the eyes of the community the company has a good image and this will have a positive impact on financial performance. However, the results are not significant due to the strong stigma attached to mining companies as the environmental destruction caused by the company's operating activities. This will take a longer time to build an image, moreover, the ability and openness of each company engaged in this sector is also different. The absence of environmental disclosure rules in Indonesia causes the lack of information of the report so that it can affect investors' views of the company (Eriandani and Wijaya, 2021, Jo and Na, 2012). Another argument that strengthens this research is that the behavior of investors in Indonesia does not yet have a high interest in environmental issues so that environmental disclosure has not become a sensitive issue (Mulyadi and Anwar, 2011). Investors have a low perception of CSR disclosure because it is only an obligation and not voluntarily or only to avoid sanctions from the government because public companies must disclose their CSR in accordance 
with the Limited Liability Company Law no. 40 of 2007 that exists (Dewi and Monalisa, 2016).

In Table 5 model 3 (non-mining sector), CSR has a significant positive effect on financial performance. This result is supported by Feng et al. (2017), Sial et al. (2018), Nyeadi et al. (2018), Yoon and Chung (2018) and Gantino (2016) who state that better CSR implementation can have a good impact on the company's longterm sustainability (sustainable development).The more CSR activities reported, the better in the eyes of investors and potential investors. CSR disclosure shows that the company is responsible for applicable regulations, the surrounding community and the natural environment. In addition, companies engaged in plantations and manufacturing do not have a "burden" of reputation that is too bad in the eyes of stakeholders so that the disclosures can improve the company's image in the eyes of stakeholders (Purnaningsih, 2018). Other supporting research, namely Almilia and Wijayanto (2007), state that companies which have good environmental disclosure will be responded positively by investors. If the company can maximize the benefits received by stakeholders, there will be satisfaction in stakeholders and this will increase the value of the company. Accordingly, it will have an impact on increasing financial performance (Miranti \& Henny, 2013).

\section{The Effects of Leverage on Tobin's Q.}

In Table 3 (model 1), 4 (model 2) and 5 (model 3), all of them show that leverage has a significant negative effect on Tobin's Q. This result is supported by Putra and Wirajaya (2013) and Barnea and Rubin (2010), who state that the more debt, the profit will be used to pay debts, interest to creditors, and costs incurred from debt so that the company's performance is getting lower. This indicates that debt shows that the burden borne by the company on creditors is getting bigger because the assets owned by the company are mostly financed by debt, so that the company's dependence on creditors is increasing. A low debt ratio does not always guarantee a low return on profits. Conversely, a high debt ratio is not a guarantee of an increase in financial performance because the company does not only depend on debt as a source of funds in running its business (Cahyana \& Suhendah, 2015). Another supporting study is the one by Istiak and Serletis (2020) which finds the higher the leverage value in financial statement ratios, the greater the risk faced by investors. The use of high debt can have an impact on the sustainability of the company and can be a burden in carrying out its operational activities that reduce financial performance. The company will also be worse if it uses too much debt because the risk is greater than the increase in company profits (Isbanah, 2015).

\section{The Effect of Firm Age on Tobin's Q.}

Tables 3 (model 1) and 4 (model 2) show that firm age has a significant positive effect at the $5 \%$ and $10 \%$ levels on financial performance. The results of this study contradict the research of Sial et al. (2018), Kao et al. (2018), and Nyeadi et al. (2018).The longer the company is established, the company has the ability to learn to improve its operational strategy from experience during operation (Cahyana \& Suhendah, 2015). However, in the third model (Table 5), firm age has no effect on financial performance. This is because the longer age of the company does not make higher profits than the newly established company, because at a certain time the income of a company that has been around for a long time will decrease due to the emergence of new competitors or startups (Abdul et al., 2017). New companies have the ability to produce good output, therefore age has no effect on financial performance. 


\section{The Effect of Firm Size on Tobin's Q.}

Firm size in the three models has a significant negative relationship with Tobin's Q. This result is supported by Gala and Julio (2016), who proves that giant companies have small Tobin's Q and small companies have large Tobin's Q. Research by Meca and Ballesta (2011), De Miguel et al. (2004), and Liu Fu (2017) found that the larger the company, the more complicated the bureaucracy is and can lead to more serious problems such as information asymmetry and lack of flexibility in responding to changes in business conditions so that financial performance declines. The bigger the company is, the bigger the operational costs will be. HR costs and depreciation will be higher and cause a decrease in profit (Ruspandi \& Asma, 2014). Usually, small companies are actually more efficient in managing their assets since the company's burden is not too large so that the company's operations can run effectively and get a higher rate of return (Cahyana \& Suhenda, 2019).

\section{Effect of Firm Employee on Tobin's Q.}

Firm employee in models 1 and 3 has a significant positive relationship with Tobin's Q, while in model 2, it has no effect. The results of this study for models 1 and 3 contradict Feng et al. (2017), Kao et al. (2018), Sial et al. (2018), and Nyeadi et al. (2018). The more the employees working in the company, it will increase diversity and also better governance management so that it can create positive work activities and form an ethical corporate culture (Carter et al, 2007). A positive corporate culture and a comfortable work environment will increase employee's motivation to work so that they have a strong commitment and reduce the error rate. Accordingly, it will have a positive effect on financial performance. Magdalena et al. (2017) found that the greater the number of employees, the better the financial performance will be. The number of employees is one of the important assets to be developed in realizing maximum profit. Companies need to increase the number and quality of employees to increase work productivity.

Meanwhile, for the mining industry, employees have no effect on financial performance in the mining sector because companies operating in this sector face many risks such as environmental risks, safety risks, liability risks, and reputation risks (Spence, 2011, Mahrani and Soewarno, 2018). Mining companies are expected to meet strict standards regarding environmental regulations and are committed to complying with them in carrying out their operations. With limited resources, the company still prioritizes CSR. Environmental orientation is crucial for long-term success (Hine \& Preuss, 2009).

\section{CONCLUSION AND RECOMMEN- DATION}

\section{Conclusion}

From the analysis that has been processed and discussed in the previous chapter, there are five variables included in the financial performance model, namely corporate social responsibility, leverage, firm age, firm size, and firm employee. The regression results show that the CSR variable to Tobin's $Q$ has a negative relationship, but this negative result is in accordance with the hypothesis, considering that the measurement method of this study is seen from the negative side. The next independent variable, namely leverage, in this study produced the same results, that is, all have a significant negative relationship with Tobin's Q.

The next is the use of three control variables, namely firm age, firm size, and firm employee. For the firm age, the regression appears to have a significant positive relationship with Tobin's Q. Then, for the firm size, it has a negative relationship with Tobin's Q. The last variable is firm employee which has a 
significant positive relationship with Tobin's Q.

This study provides information for companies that size has an influence on financial performance. Therefore, it is better for the large companies to improve their governance in order to minimize problems in the company. In addition, companies should manage their debts so that they do not exceed the optimal point of use of debt. Therefore, the debt should make a positive contribution to the company and not to add burdens to the company since this, in turn, can increase the risk faced by the company.

\section{Recommendation}

Investors can use this research as a reference in making considerations before investing in companies in Indonesia. Therefore, investors are advised to be more selective if they want to invest in companies that are large and have high debt. Investors should also be more careful and understand the future business prospects of the company, whether in the future this company still has bright prospects in running its business as well as seeing the company's ability to carry out its obligations. This is necessary so that investors are not trapped by investing in companies whose financial conditions are not so good and there may even be a risk of bankruptcy.

This research can be used by further researchers. However, this research has limitations, that is, this study only used high profile industries whose companies were listed at the Indonesian Stock Exchange in the 2015-2019 period. Then, this study also did not calculate the exact number of companies that were included in the State-Owned Enterprise (SOE-BUMN) category. For further research, it is hoped that it can add the research period, the company sector and considered the number of companies that are members of the SOE/ BUMN category.

\section{REFERENCES}

Abdi, Y., Li, X., \& Càmara, X. (2021). Exploring the impact of sustainability ( ESG ) disclosure on firm value and financial performance ( FP) in airline industry: the moderating role of size and age. Environment, Development and Sustainability, 0123456789. https://doi.org/10.1007/s10668-02101649-w

Aguinis, H. (2012). What We Know and Don ' $t$ Know About Corporate Social Responsibility: A Review and Research Agenda. 38(4). https://doi.org/10.1177/01492063114 36079

Ali, M. (2020). Impact of Leverage on Financial Performance (Evidence from Pakistan Food and Fertilizer Sector). Journal of Critical Reviews. 7(13), 447-456. http://dx.doi.org/10.31838/jcr.07.13.7 9

Barnett, M. L. (2019). The Business Case for Corporate Social Responsibility: A Critique and an Indirect Path Forward. https://doi.org/10.1177/00076503166 60044

Bazillier, R., Hatte, S., \& Vauday, J. (2017). Are environmentally responsible firms less vulnerable when investing abroad? The role of reputation. Journal of Comparative Economics, 45(3), 520-543.

Benlemlih, M., Shaukat, A., Qiu, Y., \& Trojanowski, G. (2016). Environmental and Social Disclosures and Firm Risk. Journal of Business Ethics, June 2015. https://doi.org/10.1007/s10551-0163285-5

Berezinets, I., Ilina, Y., \& Cherkasskaya, A. (2017). Board structure, board committees and corporate performance in Russia. 43(10), 10731092. https://doi.org/10.1108/MF-112015-0308 
Brown, T. J., Dacin, P. A., Pratt, M. G., \& Whetten, D. A. (2006). Identity , Intended Image, Construed Image, and Reputation: An Interdisciplinary Framework and Suggested Terminology. 34(2), 99-106. https://doi.org/10.1177/00920703052 84969

Cahyana, A. M. K., \& Suhendah, R. (2020). Pengaruh Leverage, Firm Size, Firm Age, dan Sales Growth Terhadap Kinerja Keuangan. Jurnal Paradigma Akuntansi, 2(4), 17911798.

Carter, D. A., Simkins, B. J., \& Simpson, W. G. (2003). Corporate governance, board diversity, and firm value. The Financial Review, 38, 33-53.

Chandra, N.A., Mahadwartha, P.A., \& Murhadi, W.R. (2015). Pengaruh Corporate Social Responsibility Bidang Lingkungan dan Good Corporate Governance terhadap Kinerja Perusahaan. Prosiding Forum Manajemen Indonesia (FMI) 7.

Chiu, S., \& Sharfman, M. (2011). Legitimacy, Visibility, and the Antecedents of Corporate Social Performance: An Investigation of the Instrumental Perspective. 37(6), 1558-1585.

https://doi.org/10.1177/01492063093 47958

Cho, E., \& Chun, S. (n.d.). Asia-Pacific Journal of Accounting \& Corporate social responsibility, real activities earnings management, and corporate governance: evidence from Korea. August 2015. https://doi.org/10.1080/16081625.201 5.1047005

De Miguel, A., Pindado, J., \& De la Torre, C. (2004). Ownership structure and firm value: New evidence from Spain. Strategic Management Journal, 25(12), 1199-1207.
Devie, D., Liman, L. P., Tarigan, J., \& Jie, F. (2020). Corporate social responsibility, fi nancial performance and risk in Indonesian natural resources industry. 16(1), 73-90. https://doi.org/10.1108/SRJ-06-20180155

Dewi, K. (2016). Effect Of Corporate Social Responsibility Disclosure On Financial Performance. 7(August), 149-155. https://doi.org/10.21512/bbr.v7i2.168 7

Di, P. L.-, Pandemi, M., \& Amin, M. (2021). E-JRA Vol. 10 No. 06 Agustus 2021 Fakultas Ekonomi dan Bisnis Universitas Islam Malang. 10(06), 84-91.

Eriandani, R., \& Wijaya, L. I. (2021). Corporate Social Responsibility and Firm Risk: Controversial Versus Noncontroversial Industries. 8(3), 953-965.

https://doi.org/10.13106/jafeb.2021.v ol8.no3.0953

Feng, M., X. A. Wang, \& J. G. Kreuze. (2017). Corporate Social Responsibility and Firm Financial Performance: Comparison Analyses Across Industries and CSR Categories. American Journal of Business, 32(4):106-133.

Ferraris, A., Belyaeva, Z., \& Bresciani, S. (2018). The role of universities in the Smart City innovation: Multistakeholder integration and engagement perspectives. Journal of Business Research, March, 0-1. https://doi.org/10.1016/j.jbusres.2018. 12.010

Freeman, R. (1994). The Politics of Stakeholder Theory: Some Future Directions. Business Ethics Quaterty. 4(4), 409-421. https://doi.org/10.2307/3857340

Gala, V., Julio, B. (2016). Firm Size and Corporate Investment 
Gantino, R. (2016). Pengaruh Corporate Social Responsibility Terhadap Konerja Keuangan Perusahaan Manufaktur yang Terdaftar di Bursa Efek Indonesia Periode 2008-2014. Jurnal Dinamika Akuntansi dan Bisnis. 3(2), 19-32.

Gibson, K. (2000). The Moral Basis of Stakeholder Theory. Journal of Business Ethics. 26(3), 245-257.

Hanim, S., Hanim, A. (2017). The Impact of Sustainable Manufacturing Practices on Sustainability Performance: Empirical Evidence from Malaysia. International Journal of Operations \& Production Management. $37(2)$. http://dx.doi.org/10.1108/IJOPM-042015-0223

Hatte, S., Vauday, J., Hatte, S., \& Vauday, J. (2016). PT US CR. https://doi.org/10.1016/j.jce.2016.12.0 05

Healy, P. M., \& Palepu, K. G. (2001). Information asymmetry, corporate disclosure, and the capital markets: $A$ review of the empirical disclosure literature \$. 31, 405-440.

Hill, C. (2010). Corporate Responsibility And Financial Performance: The Role Of Intangible. 490(September 2009), 463-490. https://doi.org/10.1002/smj

Ibrahim, M. (2017). Capital Structure and Firm Value in Nigerian Listed Manufacturing Companies: an Empirical Investigation Using Tobin's Q Model. 4(2), 112-125.

Isbanah, Y. (2015). Pengaruh ESOP, Leverage, dan Ukuran Perusahaan terhadap Kinerja Keuangan Persahaan di Bursa Efek Indonesia. Journal of Research in Economics and Management. 15(1), 28-41. https://doi.org/10.17970/jrem.15.1501 03.ID
Istiak, K., \& Serletis, A. (2020). Risk, uncertainty, and leverage. Economic Modelling, 91(May), 257-273. https://doi.org/10.1016/j.econmod.202 0.06 .010

Jo, H., \& Harjoto, M. A. (2011). Corporate Governance and Firm Value: The Impact of Corporate Social Responsibility. 351-383. https://doi.org/10.1007/s10551-0110869-y

Kao, E. H., Yeh, C., Wang, L., \& Fung, H. (2018). Paci fi c-Basin Finance Journal The relationship between CSR and performance: Evidence in China. 51(April), 155-170. https://doi.org/10.1016/j.pacfin.2018. 04.006

Kim, H. L., Rhou, Y., Uysal, M., \& Kwon, N. (2017). An examination of the links between corporate social responsibility (CSR) and its internal consequences. International Journal of Hospitality Management, 61, 2634.

Leuz, C., \& Verrecchia, R. E. (2013). The Economic Consequences Increased Disclosure. 38(2000), 91-124.

Lina, H., Rhou, Y., Uysal, M., \& Kwon, N. (2017). International Journal of Hospitality Management An examination of the links between corporate social responsibility ( CSR ) and its internal consequences. International Journal of Hospitality Management, $\quad 61, \quad 26-34$. https://doi.org/10.1016/j.ijhm.2016.10 .011

Linsey, P. M., \& Shrives, P. J. (2006). Risk reporting: a study of risk disclosures in the annual reports of UK companies. The British Accounting Review, 38(4), 387-404.

Magdalena, S. (2017). Pengaruh Firm Size Dan Good Corporate Governance Serta Corporate Social Responsibility Terhadap Kinerja Keuangan Pada Bank Umum Syariah Di Indonesia. 5, 221-238. 
Mahrani, M., \& Soewarno, N. (2018). The effect of good corporate governance mechanism and corporate social responsibility on financial performance with earnings management as mediating variable. 3(1), 41-60. https://doi.org/10.1108/AJAR-062018-0008

Maria, A., Cahyana, K., Suhendah, R., Ekonomi, F., \& Tarumanagara, U. (2020). Pengaruh Leverage , Firm Size, Firm Age Dan Sales Growth Terhadap Kinerja Keuangan. 2, 1791-1798.

Meca, Emma García, Juan Pedro SánchezBallesta, (2011), Firm value and ownership structure in the Spanish capital market, Corporate Governance, Vol. 11(1): $41-53$

Mishra, S., \& Suar, D. (2010). Does corporate social responsibility influence firm performance of Indian companies? In Journal of Business Ethics (Vol. 95, Issue 4). https://doi.org/10.1007/s10551-0100441-1

Mulyadi, M. S., Anwar, Y. (2012). Impact of corporate social responsibility toward firm value and profitability. The Business Review, Cambridge, 19(2), 316-322.

Muttakin, M. B., \& Khan, A. (2015). Firm characteristics, board diversity and corporate social responsibility. 27(3), 353-372.

https://doi.org/10.1108/PAR-01-20130007

Nyeadi, J. D. (2018). Corporate social responsibility and fi nancial performance nexus Empirical evidence from South African listed firms. 9(3), 301-328. https://doi.org/10.1108/JGR-01-20180004
Ozdemir, O., \& Kim, M. (2020). Corporate social responsibility and idiosyncratic risk in the restaurant industry: does brand diversi fi cation matter? 2925-2946. https://doi.org/10.1108/IJCHM-032020-0167

Phoprachak, D., \& Buntornwon, T. (2020). Influence of firm size on the environmental disclosure and performance of the listed companies on the Stock Exchange of Thailand. In Responsible business in a changing world (pp. 159-170). Springer, Cham.

Rahmawardani, D. D. (2020). Corporate Social Responsibility Terhadap Manajemen Laba Dan Kinerja Perusahaan. 12(2), 52-59.

Raiborn, C., Payne, D., \& Joyner, B. (n.d.). Environmentally Friendly Business Strategies: BP - A Case of Rhetoric or Reality? 67-89.

Rubin, A. (2010). Corporate Social Responsibility as a Conflict Between Shareholders Amir Barnea. 71-86. https://doi.org/10.1007/s10551-0100496-z

Ruspandi, H., \& Asma, R. (2016). Faktorfaktor yang mempengaruhi profitabilitas perusahaan pembiayaan di Indonesia. JWM (Jurnal Wawasan Manajemen), 2(1), 97-118.

Sa, J. P., \& Garc1, E. (2011). Firm value and ownership structure in the Spanish capital market. 11(1), 41-53. https://doi.org/10.1108/14720701111 108835

Schnackenberg, A. K., \& Tomlinson, E. C. (2014). Journal of Management. https://doi.org/10.1177/01492063145 25202

Setyawan, B., \& Zulaikha, Z. (2012). Analisis pengaruh praktik good corporate governance dan manajemen laba terhadap corporate environmental disclosure (Studi empiris pada perusahaan yang terdaftar di BEI dan PROPER Tahun 2008-2010) (Doctoral dissertation, Fakultas Ekonomika dan Bisnis) 
Shaferi, I., Wahyudi, S., Mawardi, W., Hidayat, R., \& Puspitasari, I. (2020). The Manufacture and Service Companies Differ Leverage Impact to Financial Performance. 11(2), 281286.

https://doi.org/10.5430/ijfr.v11n2p281

Sial, M. S., \& Chunmei, Z. (2018). Corporate social responsibility, firm performance and the moderating effect of earnings management in Chinese firms. https://doi.org/10.1108/APJBA-032018-0051

Soewarno, N., \& Tjahjadi, B. (2020). Measures that matter: an empirical investigation of intellectual capital and financial performance of banking firms in Indonesia. 21(6), 1085-1106. https://doi.org/10.1108/JIC-09-20190225

Statman, M., \& Glushkov, D. (2009). The Wages of Social Responsibility. 65(4), 33-46.

Surroca, J., Tribó, J. A., \& Waddock, S. (2010). Corporate responsibility and financial performance: The role of intangible resources. Strategic Management Journal,31(5), 463490.

Tangngisalu, J., Mappamiring, M., Andayani, W., \& Yusuf, M. (2020). CSR and Firm Reputation from Employee Perspective. 7(10), 171182.

https://doi.org/10.13106/jafeb.2020.v ol7.no10.171

Tingkat, P., Kas, P., Dan, P., \& Ubud, D. I. K. (2013). Pengaruh tingkat perputaran kas, piutang dan jumlah nasabah kredit pada profitabilitas lpd di kecamatan ubud. 1, 119-135.

Tsoutsoura, M. (2010). External Financing Costs for Private and Public Firms. Columbia University
Wang, X., \& Kreuze, J. G. (2017). Corporate social responsibility and firm financial performance and CSR categories. 32(3), 106-133. https://doi.org/10.1108/AJB-05-20160015

Wijayanto, D. W. I. (2007). The 1 st Accounting Conference The 1 st Accounting Conference. November, $1-23$.

Yang, S., He, F., Zhu, Q., \& Li, S. (2017). How does corporate social responsibility change capital structure? Asia-Pacific Journal of Accounting \& Economics, 1625(August), 1-36. https://doi.org/10.1080/16081625.201 7.1354710

Yoon, B., \& Chung, Y. (2018). Journal of Hospitality and Tourism Management The effects of corporate social responsibility on firm performance : A stakeholder approach. Journal of Hospitality and Tourism Management, 37(November), 89-96. https://doi.org/10.1016/j.jhtm.2018.10 .005

Yoon, E., \& Jang, S. (2005). The effect of financial leverage on profitability and risk of restaurant firms. The Journal of Hospitality Financial Management, 13(1), 35-47.

Yusof, N. A. (2019). Going beyond environmental regulations - The influence of firm size on the effect of green practices on corporate financial performance. March, 1-11. https://doi.org/10.1002/csr.1771 